Environment Conservation Journal 15(3)171-173, 2014

ISSN 0972-3099 (Print) 2278-5124 (Online)

Abstracted and Indexed

\title{
A survey of pollution-resistant plants of Nimar eco-region of Madhya Pradesh
}

\author{
S.K.Mahajan ${ }^{4}$, C.L.Dulkar', Vrinda Gupta ${ }^{2}$, Shakun Mishra ${ }^{3}$ and M.M.Keshre ${ }^{4}$ \\ Received:15.05.2014 \\ Revised:21.08.2014 \\ Accepted:07.09.2014
}

\begin{abstract}
The present communication deals with the pollution resistant plants reported from Nimar eco-region of Madhya Pradesh state. In all 49 plant species (39 dicot and 10 monocot) belonging to 45 genera ( 36 dicot and 9 monocot ) and 27 families (22 dicot and 5 monocot) are reported from angiosperm while 1 species from Pteridophyta and 2 species from Gymnosperm are reported, which are found to be pollution tolerant in this area.
\end{abstract}

Keywords: Air pollution, noise pollution, West Nimar, water pollution

\section{Introduction}

Today, in our country we are loosing our biodiversity at a greater rate. The main reasons are overpopulation, deforestation and pollution. There is no option except to develop research strategies and public policies, which can help us in conserving our biodiversity (Khanna et al, 2005). Pollution is an undesirable change in the air, water and soil. Due to this change, human beings, animals and plants are affected adversely. In Khargone city the various kinds of pollution are in fact man-made. Environmental pollution occurs due to solid, liquid, gaseous discharge and noise It was noted that four types of pollution are found to occur in Khargone and its suburbs. Dust, fly ash, coal dust and sulphur di oxide are the main causes of air pollution. Water pollution is due to the various chemicals and dissolved ash. Thermal pollution is due to increase in temperature in the area and it is unavoidable. As regards, non-residual pollution, it is due to the increase in number of vehicles which affect the nervous system and hearing organs of human beings. All the above four types of pollution have a cumulative effect in Khargone city. Sometimes plants in large and smoggy cities suffer much because of air and rain pollution. Due to this ,tender Author's Address

${ }^{1}$ Botany Deptt., Govt..College, Mandleshwar,M.P.

${ }^{2}$ Botany Department, Govt.Arts and Science P.G.College, Ratlam,M.P

${ }^{3}$ Botany Department, S.N. Govt. P.G. College, Khandwa, M.P.

${ }^{4}$ Botany Department, Govt.P.G.College,Khargone,M.P

E-mail:shrikrishna.mahajan@gmail.com plants, some tropical and edible plants can all do poorly, show stunted growth and decreased flowering. In order to see the tolerance of the plant Species few plant species such as Azadirachta indica, Ficus benghalensis, Dracaena fragrans, D.marginata, Pithecolobium dulce, Cassia siamea, Bauhinia variegate, Alstonia scholaris, Pongamia pinnata are selected, which are very common in the Khargone city and its vicinity. A survey of literature indicates that negligible research work has been done on pollution tolerant or pollution resistant plants. Mention may be made of Vashistha and Gill,1998; Tripathi et al, 2009; Nagdeve, 2002 etc.Hence the present work was undertaken.

\section{Material and Methods}

The present investigation was done during the year 2009-2010 and in this connection a survey was done on Khargone-Sanawad road, Khandwa Baroda highway, Kasrawad road and Sirwel road which are situated in Nimar eco-region of Madhya Pradesh. Various plant species were observed along roadsides and about 2-3 km interior side of the particular road.

\section{Results and discussion}

The lists of plant species observed during course of study are shown in Table 1. Plant species shown with one asterisk have very high tolerant capacity, species with 2 astersks possess high and species with 3 asterisks have less capacity for air pollution. It has been observed that large and broad leaves are 
Table 1 : Showing the list of pollution -resistant plants of Khargone and its neighbourhood

\begin{tabular}{|c|c|c|}
\hline S.No. & Name of plant species & Name of family \\
\hline 1. & Acacia nilotica & Mimosacea \\
\hline $2 * * * *$ & Alstonia scholaris & Apocynaceae \\
\hline 3 & Aristida adscensionis & Poaceae \\
\hline $4 * *$ & Azadirachta indica & Meliaceae \\
\hline $5 * * *$ & Bauhinia vasriegata & Caesalpiniaceae \\
\hline 6 & Butea monosperma & Papilionaceae \\
\hline 7 & Calotropis procera & Asclepiadaceae \\
\hline 8 & Carissa carandus & Verbenaceae \\
\hline $9 * * *$ & Cassia fistula & Caesalpiniaceae \\
\hline $10 * * *$ & Cassia siamea & Caesalpiniaceae \\
\hline 11 & Cenchrus ciliaris & Poaceae \\
\hline 12 & Croton bonplandianum & Euphorbiaceae \\
\hline 13 & Cupressus terulossa & Cupressaceae \\
\hline 14 & Cynodon dactylon & Poaceae \\
\hline 15 & Cyperus rotundus & Cyperaceae \\
\hline 16 & Dalbergia sissoo & Papilionaceae \\
\hline 17 & Datura metel & Solanaceae \\
\hline 18 & Delonix regia & Caesalpiniaceae \\
\hline 19 & Dracaena marginata & Agavaceae \\
\hline 20 & Dracaena fragrans & Agavaceae \\
\hline 21 & Echinops echinatus & Asteraceae \\
\hline 22 & Eclipta alba & Asteraceae \\
\hline 23 & Eichhornia crassipes & Pontederiaceae \\
\hline 24 & Eragrostis atrivirens & Poaceae \\
\hline 25 & Eucalyptus umbellata & Myrtaceae \\
\hline 26 & Ficus benghalensis & Moraceae \\
\hline 27 & Ficus religiosa & Moraceae \\
\hline $28 * *$ & Ficus rumphii & Moraceae \\
\hline 29 & Fimbrystylis bisumbellata & Cyperaceae \\
\hline 30 & Heliotropium indicum & Boraginaceae \\
\hline $31 *$ & Holoptelea integrefolia & Ulmaceae \\
\hline 32 & Ipomoea carnea & Convolvulaceae \\
\hline 33 & Lawsonia inermis & Lythraceae \\
\hline 34 & Lemna minor & Lemnaceae \\
\hline 35 & Madhuca latifolia & Sapotaceae \\
\hline 36 & Mangifera indica & Anacardiaceae \\
\hline 37 & Marsilea minuta & Marsileaceae \\
\hline 38 & Moringa oleifera & Moringaceae \\
\hline 39 & Parkinsonia aculeata & Caesalpiniaceae \\
\hline 40 & Pdilanthus tithimaloides & Euphorbiaceae \\
\hline $41 *$ & Pithecolobium dulce & Caesalpiniaceae \\
\hline 42 & Polygonum berbatum & Polygonaceae \\
\hline $43 *$ & Pongamia glabra & Papilionaceae \\
\hline 44 & Prosopis juliflora & Mimosaceae \\
\hline $45 *$ & Saraca indica & Caesalpiniaceae \\
\hline 46 & Solanum virgianum & Solanaceae \\
\hline 47 & Tamarindus indica & Caesalpiniaceae \\
\hline 48 & Tectona grandis & Verbenaceae \\
\hline 49 & Tephrosea purpurea & Papilionaceae \\
\hline 50 & Terminalia catappa & Combretaceae \\
\hline 51 & Thuja orientalis & Cupressaceae \\
\hline 52 & Typha angulata & Typhaceae \\
\hline
\end{tabular}

172

Environment Conservation Journal 
more sensitive to pollution such as Mangifera indica, Tectona grandis and Terminalia catappa etc. Hence if plantation of trees in areas and lawns is done, then the effect of thermal pollution may be reduced. Plants with small leaves or small leaflets would be most suitable in this area. In order to minimize the effect of noise pollution, plantation of bushes and shrubs like Carissa carandus, Lawsonia inermis, Ipomoea carnea, Pedilanthus species may be beneficial in the form of hedges inone row or two rows around the industrial or polluted areas. Some of the important plants which are resistant to air pollution are : Cassia siamea, Acacia nilotica, Tephrosia purpurea, Ficus benghalensis, Ficus religiosa, Madhuca latifolia, Butea monosperma, Parkinsonia aculeata, Datura metel, Eucalyptus umbellata, Heliotropium indicum, Croton bonplandianum, Calotropis procera, Echinops echinatus,, Pongamia pinnata, Pithecolobium dulce, Saraca indica, Holoptelea integrifolia ,Bauhinia variegata, Solanum virginianum, Aristida adscensionis, Cynodon dactylon, Cenchrus ciliaris, Prosopis juliflora, Tamarindus indica, Delonix regia and Moringa oleifera. Similarly Ficus species, Dracaena species, trees belonging to Coniferophytes, Dalbergiaetc are tolerant to nonresidual pollution or various types of noise. Hence plantations on road sides, dense evergreen hedge to reduce noise of microphones and at the source of production, imposing adequate laws to restrict excessive noise from transportation and loudspeakers during night hours in the vicinity of hospitals, institutions, libraries and residential areas are helpful to control noise pollution Important plants which are resistant to water pollution in the Nimar eco-region of Madhya Pradesh are : Typha angustata, Ipomoea carnea, Marsilea minuta,
Lemma perpusilla, Fimbristylis bisumbellata, Cyperus rotundus, Eragrostis atrovirens, Polygonum berbatum, Eclipta alba and Eichhornia crassipes. In conclusion it may said that in order to check various types of pollution, some of the above plant species may be planted around industrial areas, hospitals, libraries, big hotels and other such places where pollution problems exist, because environmental pollution is one of the serious problems faced by the people not only in urban areas of developing countries but also at National and International levels.

\section{Acknowledgements}

The authors are grateful to the Principals of Govt.P.G.College, Khargone, Ratlam, Khandwa and also Govt.College, Mandleshwar, M.P. for libraryfacilities.

\section{References}

Nagdeve, D.A. 2002. Population, Environmental pollution and its influence on health in India, Environmental education and sustainaible development in the new millennium, (eds.) DeshBandhu and ReenaAhuja, pub. Indian Environmental Society, p. 337-357.

Tripathi, A., Tiwari, P.B. and MahimaSingh,D. 2009. Assessment of air pollution tolerance index of some trees in Moradabad city, India.,J.Environ Biol., Jul.30(4):54550 .

Khanna, D.R., Chopra, A.K. and Prasad,G. 2005. Aquatic Biodiversity in India: The Present Scenario, Pub. Daya Publishing House, p.369.

Vashishta P.C. and Gill, P.S.1998.Plant Ecology and Applied Ecology, Vishal Publications, p.412. 